\title{
Terapi aktivasi perilaku untuk mengurangi perilaku menarik diri pada pasien skizofrenia
}

$\Phi$ PROCEDIA Studi Kasus dan Intervensi Psikologi p-ISSN 2302-1462; e-ISSN 2722-7669 ejournal.umm.ac.id/index.php/procedia 2021, Vol 9(4):127-133

DOI:10.22219/procedia.v9i4.16342

(c) The Author(s) 2021

(i)(\$) 4.0 International license

\author{
Aisyah Putri Rawe Mahardika ${ }^{1}$
}

\begin{abstract}
Subject in the this study experienced withdrawn behavior that is one of the negative symptoms of schizophrenia. Withdrawing is characterized by decrease in initiative behavior that can create functional impairments in life, work, relationships, social function, and self-care. The intervention used to reduce withdrawn behavior was Behavior Activation Therapy which arranged for nine sessions. The purpose of intervention was to increase daily activities by scheduling activities with monitoring. The results of the intervention showed an increase in the daily activities of the subjects. Subject begins to be able to carry out activities such as bathing, eating, taking regular medication, and cleaning the house. The success of interventions is also supported by family involvement in monitoring the activities and providing support to carry out the intervention well.
\end{abstract}

\section{Keywords}

Monitoring, scheduling, schizophrenia, Withdrawing

\section{Pendahuluan}

Skizofrenia merupakan gangguan jiwa yang diartikan sebagai jiwa yang terpecah-pecah dan adanya ketidaksesuaian antara proses berfikir, perasaan dan perbuatan. Skizofrenia dibagi menjadi beberapa tipe yaitu paranoid, hebefrenik, katatonik, skizofrenia tak terinci, depresi pasca skizofrenia, skizofrenia residual dan skizofrenia simpleks (Maslim, 2013). Skizofrenia paranoid memiliki waham yang kuat sehingga menjadi salah satu gejala yang mencolok dibandingkan dengan tipe skizofrenia lainnya. Ciri skizofrenia hebefrenik yang menonjol ialah memiliki permulaan gejala perlahan dan timbul pada masa remaja antara umur 15-25 tahun. Gejala yang timbul seperti adanya gangguan proses pikir dan gangguan kemauan (Maramis \& Maramis, 2012). Untuk menegakkan skizofrenia gejala-gejala yang khas tersebut harus telah berlangsung selama kurun waktu satu bulan atau lebih.

Gejala skizofrenia dibagi menjadi dua yaitu gejala positif dan gejala negatif (Hawari, 2014). Gejala positif mencakup adanya waham dan halusinasi. Halusinasi yaitu pengalaman panca indra tanpa ada rangsangan atau stimulus. Kekacauan alam pikiran dan gaduh gelisah. Sedangkan gejala negatif meliputi afek datar atau tumpul, menarik diri, kehilangan dorongan untuk melakukan kegiatan yang biasa dilakukan dan kurang dapat merawat diri (Nevid, 2018). Simtom penarikan diri pada gejala negatif disebut juga dengan menarik diri. Menarik diri merupakan perilaku yang ditandai dengan ketidakmampuan untuk memutuskan sesuatu, hilangnya kemauan, menjadi apatis, tidak menjaga kebersihan diri dan mengalami kesulitan dalam melakukan aktivitas sehari-hari (Davison et al., 2012).

Permasalahan diatas terjadi pada klien, yaitu kurangnya motivasi dan hilangnya minat dalam melakukan kegiatan sehari-hari, seperti mandi, makan, dan melakukan kegiatan di luar rumah. Subjek merupakan pasien yang terdiagnosa skizofrenia yang telah setelah selesai mendapatkan perawatan di RSJ. Simtom awal skizofrenia klien muncul pada usia 23 tahun. Penanganan yang telah dilakukan keluarga ialah membawa klien untuk dirawat di Pondok Pesantren. Klien dirawat di Pesantren selama tiga tahun sebelum klien kabur kembali ke rumahnya. Pada usia 30 tahun klien didiagnosis mengalami skizofrenia dan mendapatkan perawatan obat dari puskesmas tetapi pemberian obat kepada klien hanya dilakukan sebanyak satu kali karena klien merasa baik-baik saja. Setelah itu klien tidak pernah mendapatkan penanganan medis kembali sampai tahun 2019.

Adapun kejadian yang terjadi pada klien di bulan Juli tahun 2019 adalah klien mengamuk kemudian membuang perabotan rumah dan mengambil barang dagangan warga yang melintas. Setelah kejadian tersebut, klien dibawa ke RSJ untuk mendapatkan perawatan karena perilakunya

\footnotetext{
${ }^{1}$ Universitas Muhammadiyah Malang,Indonesia

Korespondensi:

Aisyah Putri Rawe Mahardika, Direktorat Program Pascasarjana, Universitas Muhammadiyah Malang, Jl. Tlogomas 246 Malang, Indonesia

Email: aisyahputrirawe@gmail.com
} 
yang semakin parah dan warga merasa terganggu. Klien dirawat di RSJ selama enam minggu, setelah pulang dari RSJ klien tidak memiliki aktivitas harian yang bermakna dan bermanfaat. Kurangnya aktivitas dan hilangnya kemauan dalam mengelola diri mengakibatkan subjek mengembangkan perilaku keseharian yang buruk, seperti mandi tidak teratur, selalu malas untuk menjalankan aktivitas, dan tidak adanya interaksi dengan lingkungan sosialnya. Hal ini menunjukkan kurangnya kemauan dalam melakukan sesuatu atau menarik diri. Berdasarkan permasalahan di atas maka intervensi yang cocok dalam mengatasi permasalahan subjek adalah terapi aktivasi perilaku.

\section{Metode Asesmen}

Asesmen untuk penegakan diagnosa yang tepat dilakukan melalui serangkaian metode antara lain: (1) Wawancara, dilakukan guna mengumpulkan informasi secara mendalam, (2) Observasi harian, (3) Tes intelegensi Weschler Adult Intelligence Scale (WAIS) untuk mengetahui kapasitas intelektual guna memprediksi seberapa jauh pemahaman klien terhadap intervensi yang akan diberikan, (4) Tes grafis berupa BAUM, Draw a Person (DAP) dan House Tree Person (HTP) untuk mengungkap kepribadian dan konsep diri klien secara mendalam yang tidak didapatkan dari hasil wawancara, (5) Tes kepribadian Thematic Apperception Test (TAT) untuk mengungkap dinamika kepribadian dalam hubungan interpersonal, dorongan emosi serta konflik pribadi yang dominan dalam diri subjek yang tidak didapatkan pada wawancara, (6) WHODAS digunakan untuk mengetahui taraf keberfungsian klien seharihari dalam pemahaman dan komunikasi dengan orang lain, pada lingkungan, perawatan diri, partisipasi dalam lingkungan sosial, kehidupan sehari-hari dan masyarakat.

\section{Presentasi Kasus}

Klien bernama Amin (inisial) berasal dari Argosari, saat pemeriksaan dilakukan klien berusia 58 tahun. Klien merupakan anak pertama dari tiga bersaudara, saudara klien meninggal saat bayi karena sakit. Sejak kanakkanak klien telah terbisa membantu ibunya bertani. Ayah klien berprofesi sebagai buruh bangunan lepas yang sering bekerja keluar kota hingga jarang berada di rumah. Klien jarang bertemu dengan ayahnya sehingga hubungan yang terjalin antara keduanya tidak begitu dekat seperti dengan ibu. Klien merasa sedih karena keadaan rumah menjadi sepi. Ibu dan klien harus bekerja untuk memenuhi kebutuhan sehari-hari karena pendapatan ayah tidak mencukupi.

Klien hanya menempuh pendidikan hingga kelas lima sekolah dasar (SD) dikarenakan ibu tidak memiliki biaya, sehingga klien berhenti sekolah dan berkegiatan untuk membantu ibu bertani. Kapasitas kecerdasan pada saat pemeriksaan pada taraf dull normal dengan full IQ 82 (standar wais), hasil tersebut menunjukkan bahwa klien mampu mengerjakan tugas-tugas yang sederhana dan mampu melaksanakan tugas-tugas yang sedikit rumit akan tetapi perlu bimbingan, klien mampu mengoptimalkan potensi yang ada dalam dirinya. Klien lebih mampu mengerjakan tugas-tugas yang membutuhkan imajinasi dan kreatifitas dibandingkan tugas-tugas yang membutuhkan logika, bahasa dan analisis.

Gejala awal skizofrenia klien muncul pada saat berusia kira-kira 23 tahun dengan peristiwa yang memicu ialah meninggalnya ayah klien dikarenakan sakit. Klien menjadi tulang punggung keluarga untuk mencari nafkah. Hal tersebut ditambah dengan kejadian saat klien tidak mendapatkan dana pensiun ayahnya sebagai veteran perang. Klien diminta mengurusi berkas-berkas dana pensiun tersebut bersama warga lainnya. Tetapi setelah menunggu, klien tidak mendapatkan dana tersebut tanpa alasan yang jelas. Hal tersebut membuat klien kecewa dan sedih karena klien sudah merencanakan akan membeli ternak.

Dua bulan berlalu setelah peristiwa tersebut, klien mulai memunculkan gejala seperti berbicara sendiri dan mengamuk tidak jelas yang membuat klien sempat dipasung beberapa hari. Klien mengatakan mulai mendengar dan melihat jin dikarenakan meminum air di tengah hutan dan mengambil buah liar saat bekerja membangun bendungan desa. Menurut hasil wawancara dengan keluarga, ayah klien diketahui seringkali berbicara dan tertawa sendiri seperti gejala yang terlihat pada klien.

Klien dirawat di Pondok Pesantren selama tiga tahun sebelum kabur kembali ke rumah karena mendapatkan perlakukan yang tidak baik menurut klien. Pada usia sekitar 30 tahun klien dibawa berobat ke Puskesmas mendapatkan obat tetapi tidak pernah kontrol karena klien merasa baik-baik saja. Sejak saat itu klien tidak pernah mendapatkan penanganan medis hingga tahun 2019. Jika klien menunjukkan gejala kekambuhan, klien dibiarkan mengamuk dan membuang perabotan dan berkeliaran mengelilingi kampung, Keluarga menyimpan seluruh barang-barang penting milik klien agar tidak menjadi sasaran untuk dibuang oleh klien. Perilaku klien tersebut dianggap warga sebagai perilaku yang dimaklumi oleh warga sekitar karena klien telah mengalami gangguan sangat lama sejak berusia muda. Hingga pada tahun 2019 pada saat hari lebaran, klien mengalami kekambuhan dan mengamuk membuang perabotan rumahnya dan mengambil barang dagangan warga. Karena situasi yang sudah tidak lagi kondusif, akhirnya keluarga dan warga sekitar membawa klien berobat ke RSJ untuk pertama kalinya.

Pemahaman diri atau insight klien pada taraf ambivalen, yaitu selama dirumah sakit klien kadang mengaku mengetahui alasan dirawat di RSJ tetapi di kesempatan yang lain klien merasa dirinya baik-baik saja dan mengaku diganggu oleh jin dan setan, bukan mengalami gangguan kejiwaan. Klien mengaku bahwa ia mengalami sakit dikarenakan kelelahan dalam bekerja dan ketempelan makhluk halus saat bekerja. 
Klien dikenal sebagai pribadi yang keras. Memiliki keinginan yang kuat jika mengharapkan sesuatu. Klien mengatakan berkeinginan untuk memperbaiki hidupnya, memiliki pekerjaan yang mudah tetapi menghasilkan pendapatan yang banyak. Klien mengatakan bahwa sempat berkeinginan merantau ke Surabaya tetapi karena tidak ada yang mengurusi ibunya sehingga ia mengurungkan niatnya dan tetap bekerja sebagai buruh tani dikampung halaman. Selama ini hasil tani klien dijual dan uangnya dibelikan perabotan rumah dan ditabung sedangkan untuk konsumsi sehari-hari klien seringkali mengambil tanpa izin hasil tani warga. Setelah ibu klien meninggal lima tahun yang lalu, klien dibantu oleh keponakan dan sepupunya dalam membersihkan rumah dan menyiapkan makanan. Karena rumah yang berdekatan sehingga keponakan setiap malamnya menginap di rumah klien.

Dalam aspek kepribadian, klien memiliki kepribadian yang introvert dan inferior, klien merasa tidak mampu hingga dalam menghadapi masalah kurang berani dan timbul perasaan malu dan ragu-ragu. Klien cenderung melakukan coping represi dalam setiap masalah yang dihadapi. Klien juga memiliki hambatan dalam mengontrol emosi, kecenderungan kecemasan dan akan menimbulkan keinginan agresi tetapi berperilaku pasif sebagai cara pertahanan seperti menghindar. Saat masih remaja mengatakan klien merasa malu dan merasa berbeda dengan teman-temannya. Ia harus bekerja untuk membeli barang yang ia inginkan, selain itu dikarenakan sejak kecil klien merasa kurang mendapatkan kasih sayang dari sosok ayahnya yang sibuk bekerja. Klien melakukan coping represi sehingga klien sangat jarang untuk mengungkapkan semua yang dirasakan seperti ketika mengalami kesedihan.

Hasil wawancara diperkuat dengan hasil berbagai alat tes kepribadian mengungkapkan bahwa klien orang yang cenderung introvert dan kurang percaya diri, memiliki ketakutan yang berlebihan sehingga tidak berani menghadapi permasalahan yang ada dan cenderung menghindari konflik. Masalah yang dialami klien diperparah dengan strategi coping atau cara klien dalam menyelesaikan masalahnya yang kurang tepat, coping stress dengan mekanisme pertahan ego yang cenderung dilakukan klien adalah escaping-avoidance yaitu cenderung menghindari permasalahan, merepres permasalahannya, dan melakukan pengingkaran.

Bentuk pengingkaran yang ditunjukkan klien yaitu pada pernikahannya, dimana klien menikah sebanyak tiga kali dengan durasi waktu pernikahan yang singkat. Menurut keluarga, klien dijodohkan dengan harapan agar gangguan yang dimiliki klien dapat berkurang. Istri klien pergi dari rumah satu hari setelah menikah dikarenakan klien menunjukkan gejala berbicara sendiri saat malam pertama pernikahan. Hal ini terjadi pula kepada istri kedua dan ketiga klien dengan pola yang sama. Kejadian ini dimaknai klien sebagai pengingkaran yaitu menyalahkan istri-istrinya yang pergi dari rumah karena tidak dibelikan sepeda motor hingga berselingkuh dengan laki-laki. Klien merasa seakan-akan klien adalah korban dan juga mengembangkan imajinasi untuk menghindari realitas yang ada karena peristiwa ditinggalkan istri merupakan kejadian yang menyakitkan dalam hidupnya.

Ketika klien ditinggal oleh istrinya, klien merasa dirinya tidak berdaya atas kejadian tersebut. Klien mempercayai bahwa istrinya meninggalkan dirinya dikarenakan keinginan yang tidak dipenuhi bukan karena kesalahan klien sepenuhnya yang menambah pengembangkan ketidakberdayaan dan harga diri yang rendah. Hal tersebut membuat simtom skizofrenia pada klien muncul seperti mengurung diri, halusinasi dan tertawa dan bicara sendiri. Klien mengaku selama ini sering kehilangan barang, seperti pakaian, sarung dan uang yang dicuri oleh tetangganya sendiri. Hal tesebut diyakini klien karena sering melihat pakaian tetangganya mirip seperti barang miliknya. Klien mengatakan kehilangan uang beberapa kali dengan jumlah besar. Motor klien pun pernah hilang diambil oleh tetangga saat klien sedang pergi bekerja, klien mengetahui pelakunya tetapi ia tidak pernah memperpanjang masalah tersebut dan memilih mengikhlaskannya. Klien takut untuk mempermasalahkan hal tersebut, ini menunjukkan bahwa klien tidak ingin mencari masalah dan mencoba menghindari konflik (escaping avoidance).

Sehari-hari klien setelah pulang berkebun, klien jarang bersosialisasi dengan tetangganya dan memilih untuk menghabiskan waktunya dengan menonton televisi di rumah. Menurut klien, mengobrol bersama tetangga tidak baik karena akan selalu bergosip tentang orang lain dan klien tidak menyukai hal tersebut. Klien pun mengatakan sering menjadi omongan beberapa tetangga yang membuat klien menjadi sedih dan marah tetapi ia tidak berani melakukan apapun dikarenakan tetangga sering menertawai klien dan tidak menghiraukan apapun yang klien katakan.

Adapun halusinasi yang ditunjukkan klien berupa halusinasi pendengaran dan penglihatan. Klien mengaku dibawa ke RSJ dikarenakan merasa bingung dan mengamuk dengan membanting peralatan rumahnya. Hal ini dikarenakan subjek mendengar bisikan dari setan yang berbentuk besar, tinggi, berwarna hitam, dan memiliki janggut yang lebat. Sosok tersebut sering membisikkan untuk selalu menjadi orang yang sabar dan selalu melakukan sholat tepat waktu. Klien juga sering mendengar suara "darrrr" yang sangat keras. Selain itu klien juga mengaku melihat sosok jin santri yang berpakaian putih. Beberapa kali melihat sosok Pak Karno sedang naik becak dan meyakini dirinya sebagai Pak Sukarno. Dinamika terbentuknya gangguan skizofrenia pada klien dapat dijelaskan melalui model diathesis stress. Diathesis stress pada skizofrenia sebagai interaksi dari diathesis genetik maupun psikologis dengan faktor stressor lingkungan (Nevid, 2018). Faktor stressor lingkungan berupa pengalaman individu dari peristiwa yang menegangkan. Individu memiliki beberapa tingkat kerentanan yang melekat untuk mengembangkan gangguan (Broerman, 2018). Jumlah intensitas stress lingkungan yang memicu gangguan tergantung pada sejauh mana kerentanan yang dimiliki 
individu. Semakin besar kerentanan individu terhadap suatu gangguan, semakin kecil jumlah stres yang dibutuhkan untuk memicu perkembangan gangguan. Sehingga interaksi ini antara diatesis dan stres dapat menjelaskan alasan individu mengalami gangguan.

Kerentanan biologis dari klien merupakan faktor keturunan yaitu dari ayah klien yang diindikasikan memiliki simtom halusinasi pendengaran, dengan ciri-ciri berbicara dan tertawa sendiri. Selain kerentanan biologis terdapat kerentanan psikologis yaitu klien merupakan pribadi yang pencemas, introvert, inferior yaitu merasa dirinya kurang mampu menghadapi tantangan serta cenderung menghindari penyelesaian masalah. Kerentanan psikologis tersebut membuat klien mengembangkan respon coping berupa penghindaran, represi dan escaping avoidance dalam masalah dan stressor lingkungan yang dialaminya sehingga menyebabkan munculnya gangguan skizofrenia.

Permasalahan klien saat ini adalah perilaku penarikan diri setelah pulang dari rawat inap di rumah sakit jiwa. Klien hanya berdiam diri tidak melakukan apapun, tidak memiliki aktifitas harian yang bermanfaat untuk dilakukan dalam kehidupan sehari-harinya pasca perawatan di rumah sakit jiwa. Kurangnya kemampuan mengelola diri dan mengembangkan perilaku merawat diri yang buruk seperti jarang mandi, berdiam diri, meninggalkan sholat, dan malas melakukan aktivitas. Perilaku ini sebagai simptom negatif atau menarik diri pada penderita skizofrenia yaitu hilangnya kemauan untuk melakukan aktifitas.

Dalam model perilaku Skinner, (A) mewakili anteseden untuk perilaku yang terbentuk, (B) mewakili perilaku dan (C) mewakili konsekuensi (memperkuat atau melemahkan rangsangan yang mengikuti perilaku) (Feist et al., 2013). Salah satu masalah yang mengakibatkan klien mengembangkan perilaku menarik diri klien setelah pulang dari rumah sakit jiwa adalah perasaan malu karena pernah menjadi pasien rumah sakit jiwa. Dalam kasus ini membuat klien mengembangkan perilaku menarik diri, (A) dengan mengembangkan perilaku menarik diri tersebut klien merasa nyaman karena tidak harus keluar rumah, (B) hal ini membuat perilaku menarik diri klien semakin diperkuat, (C) Dinamika perjalanan kasus pada klien berdasarkan teori diathesis stress, yaitu terdapat kerentanan dan stressor lingkungan yang menjadi pencetus gangguan klien. Tipe kepribadian klien membuat coping yang tidak efektif sehingga menimbulkan gejala gangguan.

\section{Diagnosis dan Prognosis}

\section{Diagnosis}

Hasil diagnosis memenuhi diagnosis skizofrenia pada DSM 5 (American Psychiatric Association, 2013) 295.90 (F20.9). Gangguan Skizofrenia meliputi adanya (A) delusi, halusinasi auditori dan visual, adanya simtom negatif yang terjadi lebih dari durasi waktu satu bulan; (B) adanya gangguan sejak gangguan muncul yaitu perawatan diri dan hubungan interpersonal yang kurang baik; (C) onset pertama skizofrenia pada subjek muncul pada usia 23 tahun, halusiansi klien terus menerus muncul hingga saat ini; (D) gejala yang diperlihatkan klien bukan merupakan gejala gangguan lainnya; (E) tidak ada riwayat penyalahgunaan zat; (F) Tidak ada gangguan spektrum autism dan gangguan komunikasi pada subjek pada masa perkembangan anak.

Permasalahan yang dialami klien adalah perilaku menarik diri yang terjadi setelah klien keluar dari rumah sakit. Permasalahan ini terjadi dikarenakan klien malu pernah menjadi pasien rumah sakit jiwa hal ini mengembangkan perilaku menarik diri klien dengan mengurung diri di dalam rumah dan tidak melakukan aktivitas lain selain melamun dan tidur. Taraf keberfungsian subjek secara umum dapat dilihat pada WHODAS dalam 30 hari terakhir dengan skor total 3,8 masuk dalam kategori sedang, sehingga kurang berfungsi dalam kehidupan sehari-hari.

\section{Prognosis}

Prognosis pada klien adalah sedang. Hal ini ditandai dengan adanya keinginan untuk berubah dan berdasar pada taraf keberfungsian klien dengan kategori sedang menandakan klien memiliki keberfungsian yang kurang. Keluarga cukup terbuka dan membantu dalam proses terapi dilakukan.

\section{Intervensi}

Intervensi yang digunakan adalah aktivasi perilaku dengan tujuan untuk mereduksi simtom menarik diri dengan meningkatan aktivitas sehari-hari klien. Menarik diri klien perlu menjadi fokus intervensi pada klien karena dapat memunculkan kembali simtom skizofrenia (Depp et al., 2011). terapi aktivasi perilaku untuk meningkatkan aktivitas subjek agar perilaku menarik diri klien berupa berdiam diri, tidak melakukan apapun, tidak memiliki aktifitas harian yang bermanfaat untuk dilakukan dalam kehidupan sehari-harinya pasca perawatan di rumah sakit jiwa. Fokus berubahan perilaku dalam intervensi ini adalah perilaku-perilaku yang sebelumnya menjadi kebiasaan klien sebelum mendapat perawatan di RSJ, seperti menjaga kebersihan diri ataupun berkegiatan di luar rumah.

Terapi aktivasi perilaku menggunakan strategi shaping penjadwalan aktivitas dan pemberian penguatan positif untuk memperkuat perilaku. Penjadwalan dilakukan dengan tingkatan kesulitan yang berbeda setiap sesinya dengan tujuan membiasakan klien dengan aktivitas yang harus dilakukan (Turner \& Leach, 2012). Penguatan yang dilakukan pada intervensi ini adalah pujian dari keluarga dan dari lingkungan sekitar dan klien dimasakkan makanan kesukaannya di keesokan harinya. Hal ini akan dilakukan dengan memberikan edukasi tentang gangguan dan penanganan terapi yang dapat dilakukan untuk mencegah kekambuhan. Seperti menyapa klien dan berkomunikasi singkat dengan klien saat klien berada di pekarangan rumah atau sedang berkebun, respon baik dari 
lingkungan, baik dari keluarga dan lingkungan. Intervensi dilakukan dalam 9 sesi, yaitu :

Sesi I: Kontrak dan pengenalan terapi. Target pada sesi ini klien memahami tujuan, proses terapi yang akan dilakukan dan berkomitmen untuk menjalankan terapi. Praktikan membantu klien mengidentifikasi keuntungan dan kekurangan saat terapi dilakukan. Praktikan menjelaskan tahap terapi yang akan dilakukan agar klien dan keluarga memahami tugas yang akan dijalankan. Respon klien mendengarkan dengan baik dengan sesekali mengangguk yang menunjukkan bahwa ia memahami penjelasan dari praktikan. Sesi ini berjalan dengan lancar dan klien kooperatif.

Sesi II: Mengidentifikasi target perubahan perilaku Target pada sesi ini ialah klien memahami perubahan perilaku yang akan diubah dan alasan mengubah perilaku tersebut. Klien dibantu keluarga diminta untuk menceritakan kegiatannya selama satu minggu setelah keluar dari rumah sakit jiwa, bahwa klien tidak melakukan apapun hanya melamun di dalam rumah, tidak melakukan kegiatan rawat diri seperti mandi dan juga tidak mau membersihkan rumahnya. Setelah itu praktikan menjelaskan bahwa perilaku tersebut merupakan perilaku maladaptif dan merupakan gejala dari skizofrenia yang dapat menyebabkan kekambuhan pada penyakit klien sehingga perilaku tersebut butuh untuk dilakukan terapi. Dalam sesi ini juga dilakukan diskusi antara klien dan praktikan. Reaksi klien saat praktikan menjelaskan mendengarkan dengan saksama dan ketika praktikan menanyakan kembali. Klien memahami perilaku-perilakunya tersebut tidak baik untuk dirinya dan harus dirubah.

Sesi III: Activity Scheduling untuk satu hari Target pada sesi ini klien menjalankan kegiatan yang sudah terjadwal selama satu hari. Untuk menetapkan kegiatan yang akan dilakukan sebagai kegiatan selama satu hari dilakukan diskusi antara klien dan praktikan tentang kegiatan yang biasanya dilakukan klien sebelum dirawat di rumah sakit. Setelah kesepakatan antara klien dan terapis, maka ditentukan kegiatan yang akan dilakukan dibagi menjadi dua sesi yaitu kegiatan pagi dan sore. Sesi pagi terdiri dari kegiatan (1) mandi, (2) makan, minum obat dan (3) membersihkan tempat tidur. Kegiatan sore terdiri dari (1) makan, minum obat, (2) menyiram tanaman dan (3) memberikan makan ternak. Klien mengangguk ketika mendengar terapis yang menandakan bahwa ia memahami penjelasan yang diberikan oleh terapis.

Jadwal dituliskan pada kertas HVS dan ditempelkan di beberapa ruangan rumah agar klien mudah menemukan dan dapat membacanya, setelah klien mengerjakan kegiatan yang sudah direncanakan, keluarga diminta untuk memberikan tanda centang untuk jadwal kegiatan yang terlaksana dan tanda silang untuk jadwal kegiatan yang tidak terlaksana. Pemberian tanda pada lembar kerja disaksikan oleh klien sambil keluarga memberikan pujian saat klien berhasil melakukan tugas dengan baik.
Sesi IV: Psikoedukasi keluarga. Target pada sesi ini adalah keluarga sebagai orang yang akan mengawasi klien memahami terapi yang sedang dijalankan klien sehingga dapat membantu memberi dukungan pada klien. Keluarga yang terdiri atas saudara perempuan dan keponakan klien antusias mendengarkan arahan. Selama ini mereka tidak memahami cara berinteraksi yang benar dengan klien. Klien dibiarkan menarik diri karena dirasa butuh waktu tenang untuk dirinya sendiri.

Sesi ini diawali dengan terapis menjelaskan tentang penyakit skizofrenia, gejala yang dapat diamati secara sederhana dan penanganan yang dapat diberikan oleh keluarga terhadap klien skizofrenia. Seperti pemberian semangat, mengingatkan tentang meminum obat dan motivasi untuk selalu berkegiatan positif. Berhubungan dengan tugas Activity Scheduling yang akan diberikan keluarga diminta untuk terus mengingatkan klien untuk melakukan kegiatannya, memberikan dukungan agar klien semangat mengerjakan tugas dengan memasakkan lauk kesukaan klien jika seluruh jadwal kegiatan dilakukan.

Sesi V: Activity Monitoring. Target pada sesi ini adalah mengecek hasil tugas aktivitas klien. Monitoring dilakukan untuk memastikan jadwal yang telah disepakati untuk dilakukan klien. Pada sesi ini terapis bertanya pada klien tentang kegiatannya selama satu hari Activity scheduling dilakukan. Klien mengatakan dari enam kegiatan yang dijadwalkan klien mengerjakan lima kegiatan, kegiatan membersihkan tempat tidur tidak dilakukan dengan alasan klien lupa. Setelah wawancara dengan klien dilakukan konfirmasi kepada keluarga yaitu keponakan yang tinggal serumah dengan klien. Keponakan klien mengatakan sudah mengingatkan untuk membersihkan tempat tidurnya tetapi klien hanya mengiyakan. Klien diberikan motivasi untuk terus melakukan kegiatan yang disepakati dan memastikan keluarga untuk selalu memantau kegiatan klien dan terus memberikan motivasi klien untuk berubah

Sesi VI: Activity scheduling lanjutan untuk satu minggu. Monitoring dilakukan untuk melihat hasil dari behavior activation selama dua minggu yang diberikan, memastikan ketercapaian aktivitas sesuai dengan jadwal yang disepakati dengan checklist yang dilakukan oleh pihak keluarga. Pada minggu pertama, dilakukan monitoring terkait kegiatan klien dan dilakukan kembali pada minggu kedua dengan hasil terdapat peningkatan kegiatan. Pada sesi ini terapis mewawancarai klien terkait dengan kesulitan yang dialami klien selama menjalankan jadwal kegiatan. Menurut klien, kegiatan mandi adalah kegiatan yang sulit dilakukan karena klien sering merasa malas untuk mandi. Selain itu kegiatan yang sering terlewat adalah menyapu rumah. Target pada sesi ini adalah klien menjalankan penjadwalan kegiatan yang telah ditentukan. Secara umum sesi ini dapat dikatakan berhasil walaupun masih ada kegiatan yang terlewati karena tidak dilakukan klien.

Sesi VII: Activity monitoring. Evaluasi dilakukan pada sesi ini terhadap tugas dan aktivitas yang telah dilakukan 
klien selama sesi dilakukan. Terapis menyimpulkan hal yang dijalani klien selama proses intervensi dengan memberikan bekal agar klien mau membiasakan diri untuk terus melakukan aktivitas dengan jadwal yang ditentukan. Perubahan positif dari kegiatan keseharian klien yang bertambah daripada sebelum diberikannya intervensi. Keluarga diminta untuk terus mengontrol meskipun proses intervensi telah selesai dan selalu memberi dukungan pada klien agar tidak lagi memunculkan perilaku menarik diri.

Sesi VIII: Evaluasi dan Terminasi. Evaluasi dilakukan pada sesi ini terhadap tugas dan aktivitas yang telah dilakukan klien selama sesi dilakukan. Terapis menyimpulkan hal yang dijalani klien selama proses intervensi dengan memberikan bekal agar klien mau membiasakan diri untuk terus melakukan aktivitas dengan jadwal yang ditentukan. Perubahan positif dari kegiatan keseharian klien yang bertambah daripada sebelum diberikannya intervensi. Keluarga diminta untuk terus mengontrol meskipun proses intervensi telah selesai dan selalu memberi dukungan pada klien agar tidak lagi memunculkan perilaku menarik diri.

Sesi IX: Follow Up. Follow up dilakukan untuk mengetahui kondisi klien setelah proses terapi berakhir dan melihat apakah kegiatan yang ditentukan masih dilaksanakan oleh klien. Kegiatan ini dilakukan dua minggu setelah intervensi berakhir dengan melakukan wawancara dengan pihak keluarga dan klien. Setelah intervensi dilakukan, klien menunjukkan perubahan perilaku yang signifikan yang ditunjukkan dengan kegiatan klien sehari-hari masih mengikuti penjadwalan yang diberikan saat intervensi. Selain kegiatan tersebut, klien sudah mulai bertani dengan menanam tumbuhan di kebun depan rumahnya.

\section{Hasil dan Pembahasan}

\section{Hasil}

Berdasarkan intervensi yang dilakukan terdapat penurunan perilaku menarik diri pada klien dengan peningkatan kegiatan sehari-hari klien. Target intervensi dapat dikatakan berhasil, walaupun tidak seluruh kegiatan dilakukan oleh klien. Hasil intervensi menunjukkan peningkatan kegiatan setiap harinya dengan berbagai aktivitas mandi, beribadah, memberi makan ternak dan menyiram tanaman.

Hasil peningkatan aktivitas harian yang dilakukan dalam data checklist kegiatan dengan total kegiatan 13 kegiatan harian yang dibagi menjadi dua sesi yaitu sesi pagi dan sesi sore dalam waktu dua minggu. Jumlah kegiatan terbanyak yang dilakukan klien ialah 12 kegiatan yang bertahan dilakukan klien selama dua hari. Selama intervensi terdapat peningkatan jumlah aktivitas yang dilakukan yang sebelumnya melamun, tidak berkegiatan menjadi mau beraktifitas secara perlahan. Peningkatan aktivitas klien tersebut (lebih jelasnya dapat dilihat pada Gambar 1.

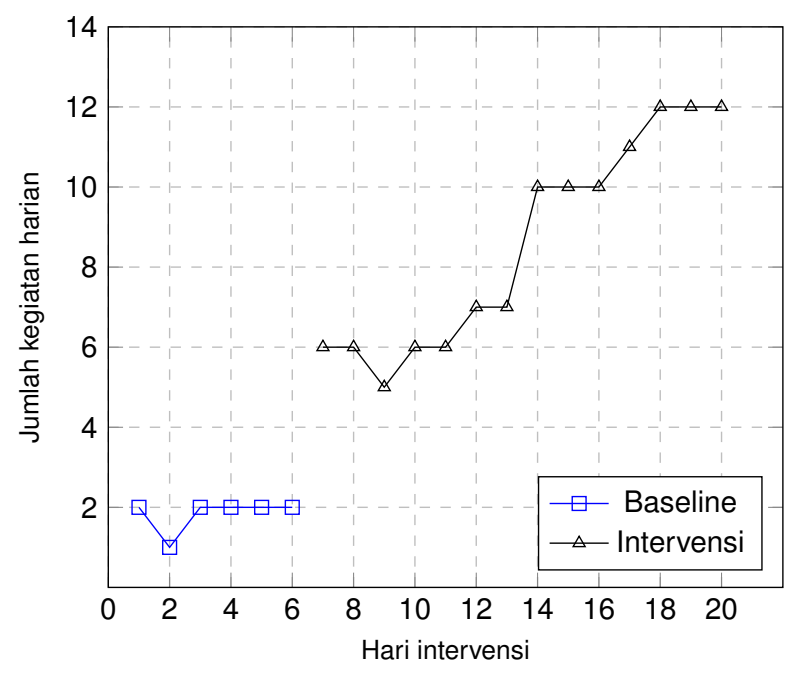

Gambar 1. Hasil intervensi.

Kegiatan yang telah dilakukan klien merupakan kegiatan yang tidak mudah bagi subjek, karena sebelum intervensi, klien menghabiskan waktunya selama satu minggu dengan duduk dan bermalas-malasan, tidak melakukan mandi dan jarang makan. Terjadinya peningkatan bertahap untuk kegiatan yang dilakukan klien adalah kemajuan yang bagus. Selain itu, dukungan dari keluarga juga berperan penting sehingga klien selalu ingat untuk melakukan tugas-tugasnya. Pada sebelum intervensi dilakukan, setiap harinya klien kurang berkegiatan yang ditunjukkan dengan jumlah kegiatan yang rendah, sedangkan setelah intervensi terlihat peningkatan yang cukup baik dan meningkat setiap harinya.

\section{Pembahasan}

Permasalahan yang dialami klien adalah perilaku menarik diri. Perilaku menarik diri diartikan sebagai penurunan perilaku insiatif diri (Trémeau, 2012). Perilaku menarik diri pada klien terjadi karena perasaan malu pernah dirawat di rumah sakit dan perkataan beberapa tetangga yang mengatakan bahwa klien belum sembuh tetapi sudah dipulangkan. Perilaku ini menjadi gejala inti dari skizofrenia yang membuat gangguan fungsional pada kehidupan, pekerjaan, hubungan, fungsi sosial dan perawatan diri (Harvey et al., 2007).

Dalam terapi aktivasi perilaku terdapat pembentukan atau shaping yaitu perilaku yang dilakukan secara terus menerus, perilaku yang diperkuat akan membuat terciptanya pencapaian perilaku sehat (Turner \& Leach, 2012). Dengan dilakukannya penjadualan aktivitas setiap harinya merupakan pembentukan yang disengaja agar perilaku yang lebih positif klien dapat terbentuk. Hasil intervensi yang dilakukan, menunjukkan bahwa terjadinya perubahan perilaku yang signifikan. Hal tersebut ditunjukkan dengan meningkatnya kegiatan klien selama intervensi dilakukan, berdasar pada baseline kegiatan klien setiap harinya klien 
melakukan kegiatan makan dan minum obat saja selama empat hari mengalami peningkatan.

Perubahan perilaku yang ditunjukkan mendapatkan penguatan berupa respon positif dari lingkungan. Keluarga dan tetangga terdekat klien diberikan pengetahuan tentang gangguan yang dimiliki serta intervensi yang akan diberikan sehingga dapat membantu jalannya intervensi dengan memonitori aktivitas klien sehari-hari. Hal ini membuat perilaku menarik diri yang bersumber dari klien merasa tetangga yang membicarakannya tidak terjadi. Motivasi internal klien menjadi fokus penting dalam keberhasilan intervensi yang diberikan. Klien memiliki keinginan untuk melakukan terapi agar perilaku menarik dirinya bisa berkurang karena klien mengetahui bahwa perilaku tersebut tidak baik untuk dirinya.

\section{Simpulan}

Pemberian intervensi behavior activation dapat membantu dalam menurunkan perilaku penarikan diri pada klien. Terdapat peningkatan jumlah kegiatan selama intervensi dilakukan. Setelah follow up, kegiatan klien seharihari masih mengikuti penjadwalan yang diberikan saat intervensi. Selain kegiatan tersebut klien sudah mulai bertani dengan menanam tumbuhan di kebun depan rumahnya.

\section{Referensi}

American Psychiatric Association. (2013).Diagnostic and Statistical Manual of Mental Disorders. In Arlington (5th ed.). https://doi.org/10.1176/appi.books.9780890425596.744053

Broerman, R. (2018).Diathesis-Stress Model. Encyclopedia of Personality and Individual Differences, 10-12.

Davison, G. C., Neale, J. M., \& Kring, A. M. (2012). Psikologi Abnormal. Jakarta: PT Raja Grafindo Persada.
Depp, C. A., Cardenas, V., Harris, S., Vahia, I. V., Patterson, T. L., \& Mausbach, B. T. (2011). Psychopathological and functional correlates of behavioral activation and avoidance in schizophrenia. Journal of Nervous and Mental Disease, 199(11), 861-865. https://doi.org/10.1097/NMD. 0b013e3182349cb7

Feist, J., \& Feist, G. j. (2013). Teori Kepribadian (7th ed.). Jakarta: Salemba Humanika.

Harvey, P. D., Velligan, D. I., \& Bellack, A. S. (2007). Performance-based measures of functional skills: Usefulness in clinical treatment studies. Schizophrenia Bulletin, 33(5), 1138-1148. https://doi.org/10.1093/schbul/sbm040

Hawari, D. (2014). emphSkizofrenia. Jakarta: FK UI.

Maramis, W. F., \& Maramis, A. A. (2012). emphCatatan Ilmu Kedokteran Jiwa (kedua). Surabaya: Airlangga University Press.

Maslim, R. (2013). Buku Saku Diagnostik Gangguan Jiwa. Jakarta: FK Unika Atmajaya.

Nevid, J. S., Rathus, S. A., \& Greene, B. (2018). Psikologi abnormal di Dunia yang terus berubah (Kesembilan). Jakarta: Erlangga.

Sadock, B. J., \& Sadock, V. A. (2010). Buku Ajar Psikiatri Klinis (Kedua). Jakarta: EGC.

Schunk, D. H. (2012). Learing Theories an Educational Perspective (Sixth Edit). Boston: Pearson.

Trémeau, F., Nolan, K. A., Malaspina, D., \& Javitt, D. C. (2012). Behavioral validation of avolition in schizophrenia. Schizophrenia Research, 138, 255-261. https://doi.org/10. 1016/j.schres.2012.02.018

Turner, J. S., \& Leach, D. J. (2012). Behavioural activation therapy: Philosophy, concepts, and techniques. Behaviour Change, 29(2), 77-96. https://doi.org/10.1017/bec.2012.3

Veale, D. (2008). Behavioural activation for depression. Advances in Psychiatric Treatment, 14(1), 29-36. https://doi.org/10. 1192/apt.bp.107.004051 